Berkala Ilmu Perpustakaan dan Informasi, Vol. 13, No. 2, Desember 2017, Hal. 217-226 DOI: http:// 10.22146/bip.27564

ISSN 1693-7740 (Print), ISSN 2477-0361 (Online)

Tersedia online di https://jurnal.ugm.ac.id/bip

\title{
ANALISIS PEMANFAATAN RUMAH BACA APUNG OLEH MASYARAKAT DI DESA TAMBAK LOROK
}

\author{
Rizki Nurislaminingsih Roro Isyawati Permata Ganggi ${ }^{1}$ \\ 'Prodi S1 Ilmu Perpustakaan Fakultas Ilmu Budaya Universitas Diponegoro \\ e-mail: rizkinurvega@gmail.com
}

Naskah diterima: 17 Agustus 2017, direvisi: 4 September 2017, disetujui: 13 Oktober 2017

\begin{abstract}
ABSTRAK
Rumah Baca Apung yang terletak di Desa Tambak Lorok merupakan aset berharga milik warga yang dapat dimanfaatkan sebagai balai pertemuan dan perpustakaan desa. Pada kenyataannya Rumah Baca Apung belum dimanfaatkan secara optimal sesuai dengan fungsi dan tujuan pembangunan sebuah perpustakaan. Berdasarkan observasi awal peneliti dapat diketahui bahwa lokasi tersebut lebih sering dimanfaatkan sebagai tempat berdiskusi bagi warga sekitar. Oleh sebab itu penelitian ini bertujuan untuk mengkaji lebih jauh pemanfaatan Rumah Baca Apung dan alasan yang melatarbelakangi pemanfaatan. Penelitian ini menggunakan pendekatan kualitatif studi kasus dengan teknik pengumpulan data melalui wawancara, studi dokumentasi dan observasi. Hasil penelitian ini menunjukkan pemanfaatan Rumah Baca Apung belum berdasarkan pada fungsi pendidikan, penelitian dan fungsi pelestarian dari sebuah perpustakaan. Rumah Baca Apung juga belum dimanfaatkan sebagai tempat untuk meningkatkan gemar membaca. Rumah Baca Apung kini dimanfaatkan sebagai tempat rekreasi, tempat berdiskusi, bersosialisasi dan penyuluhan bagi warga sekitar. Pemanfaatan Rumah Baca Apung yang belum merepresentasikan fungsi perpustakaan desa disebabkan oleh keterbatasan kuantitas dan kualitas buku yang menjadi koleksi, kurangnya mainan edukatif serta ketiadaan sukarelawan guru pendamping belajar bagi anak-anak pesisir Tambak Lorok.
\end{abstract}

Kata kunci: Pemanfaatan; Rumah Baca Apung; Tambak Lorok

\begin{abstract}
Located in Tambak Lorok Village, Rumah Baca Apung is a valuable asset in the community. The main purpose of the library is to be used as a meeting hall and village library. In fact Rumah Baca Apung has not been utilized optimally. Based on preliminary observations, Rumah Baca Apung was used as a discussion place by the local people. Therefore, this study is conducted to examine the utilization of Rumah Baca Apung and its reasons.. This research uses qualitative approach with a case study through interview, documentation study, and observations. The results show that the use of Rumah Baca Apung has not been used based on the function of education, research and preservation of a library. Rumah Baca Apung also has not been used as a place to increase reading habit. Rumah Baca Apung is currently used as a place of recreation, a place to discuss andsocialize.. The utilization of Rumah Baca Apung which has not yet represented the function of the village library is due to the limited quantity and quality of the collections, the lack of educative games equipment, and the limited number of teachers or volunteers.
\end{abstract}

Keywords: Utilization; Rumah Baca Apung; Tambak Lorok 


\section{A. PENDAhuluan}

Desa Tambak Lorok telah memiliki Rumah Baca Apung yang merupakan hibah dari Kementerian Pekerjaan Umum dan Perumahan Rakyat Republik Indonesia yang memiliki kepedulian di bidang pendidikan bagi masyarakat desa tersebut. Pada perkembangannya Rumah Baca Apung belum dimanfaatkan secara maksimal sebagai sumber ilmu pengetahuan melalui koleksi pustaka. Hal ini dibuktikan berdasarkan pengamatan awal peneliti, Rumah Baca Apung tersebut lebih sering digunakan anak-anak hanya untuk kegiatan bermain dibandingkan belajar. Rumah Baca Apung juga pernah dimanfaatkan oleh mahasiswa dari sebuah universitas di Semarang untuk mengadakan kegiatan senam bersama anak-anak pesisir Tambak Lorok.

Hasil percakapan peneliti pada observasi awal dengan salah satu warga (informan 1) juga menunjukkan hal serupa. Informan 1 mengakui, pada awal berdirinya, yakni di bulan November 2016 Rumah Baca Apung sempat digunakan oleh warga untuk kegiatan belajar sembari bermain bagi anak-anak. Lebih lanjut informan 1 menyatakan, kini bangunan tersebut lebih sering digunakan sebagai tempat berkumpul masyarakat untuk berdiskusi.

Kenyataan tentang pemanfaatan Rumah Baca Apung oleh warga Tambak Lorok menjadi hal menarik yang perlu untuk diteliti lebih lanjut. Rumah Baca Apung yang sejatinya merupakan representasi dari perpustakaan desa belum dimanfaatkan secara optimal sebagai tempat untuk membaca atau mencari ilmu pengetahuan tambahan di luar bangku sekolah. Fungsi perpustakaan desa sebagai perpanjangan tangan dari dunia pendidikan telah dijelaskan dalam Undang-Undang No 43 Tahun 2007 tentang Perpustakaan pasal 22 ayat 4 bahwa "masyarakat dapat menyelenggarakan perpustakaan umum untuk memfasilitasi terwujudnya masyarakat pembelajar sepanjang hayat".

Serupa dengan penjelasan tentang tujuan dan manfaat perpustakaan dalam UndangUndang No 43 Tahun 2007 tentang Perpustakaan, pendirian Rumah Baca Apung di Tambak Lorok juga memiliki tujuan yang sama.
Hal ini dijelaskan Fadli -(2016) bahwa pembangunan Rumah Baca Apung bermula dari usulan warga masyarakat di Tambak Lorok yang merasa membutuhkan balai pertemuan dan perpustakaan desa. Berdasarkan kebutuhan tersebut lahirlah konsep Bangunan Apung yang terdiri dari dua lantai masing-masing untuk balai pertemuan warga dan perpustakaan desa. Ruang di lantai dua yang dikhususkan untuk perpustakaan dibuat berdasarkan hasil observasi tim Balitbang Kementerian PUPR yang telah menemukan fakta bahwa edukasi literasi di kawasan Tambak Lorok sangat minim.

Berdasarkan pengamatan awal peneliti di lapangan dan hasil kajian pada tujuan awal pendirian Rumah Baca Apung yang telah dijelaskan oleh Fadli (2016) tersebut, dapat dipahami bahwa pemanfaatan Rumah Baca Apung belum mencerminkan manfaat sebuah perpustakaan. Pemanfaatan Rumah Baca Apung yang terkesan jauh dari aktivitas belajar dan membaca buku juga berbanding terbalik dengan hasil kajian peneliti pada penelitian sebelumnya.

Penelitian Nurislaminingsih (2016) menunjukkan bahwa para nelayan di desa Tambak Lorok mengakui membutuhkan sebuah perpustakaan untuk menjadi sumber ilmu pengetahuan bagi warga, termasuk bagi anakanak usia sekolah. Hal ini didasarkan pada kebutuhan warga akan tambahan berbagai pengetahuan seperti penanganan sampah, penanggulangan banjir hingga peningkatan kreativitas. Kebutuhan akan perpustakaan tersebut juga didasarkan pada alasan minimnya fasilitas pendidikan di desa Tambak Lorok yang hanya memiliki satu sekolah, yakni Sekolah Dasar Takwiyatul Waton.

Berdasarkan penelitian (Nurislaminingsih, 2016) dapat dipahami bahwa nelayan di desa Tambak Lorok mempersepsikan perpustakaan sebagai tempat untuk mencari ilmu pengetahuan melalui buku yang menjadi koleksi. Selain itu, tergambar pula harapan akan berdirinya perpustakaan desa di wilayah Tambak Lorok. Namun demikian kenyataan di lapangan menunjukkan bahwa setelah adanya Rumah Baca Apung, masyarakat masih belum memanfaatkan perpustakaan desa tersebut 
secara optimal sebagai tempat untuk membaca, menimba ilmu pengetahuan dan sarana belajar.

Berdasarkan permasalahan yang telah dipaparkan di atas, maka pertanyaan penelitian ini adalah "Bagaimana pemanfaatan Rumah Baca Apung oleh masyarakat di Desa Tambak Lorok dan apa alasan masyarakat melakukan kegiatan tersebut?".

\section{B. TINJAUAN PUSTAKA}

Penelitian ini merupakan penelitian lanjutan dari penelitian sebelumnya (Nurislaminingsih, 2016) yang berjudul "Attitudes of Fishermen in Tambak Lorok on Library". Pada penelitian tersebut diperoleh gambaran sikap nelayan pesisir Tambak Lorok terhadap perpustakaan yang terlihat dari persepsi, perasaan (suka atau tidak suka) dan kecenderungan perilaku (menginginkan atau menolak) perpustakaan.

Hasil dari penelitian (Nurislaminingsih, 2016) menunjukkan bahwa perpustakaan dipersepsikan sebagai tempat untuk mencari pengetahuan dan tempat bermain yang positif bagi anak-anak. Nelayan juga mengungkapkan perasaan senang apabila sebuah perpustakaan desa dapat berdiri di pesisir Tambak Lorok. Nelayan berharap adanya perpustakaan desa dapat membantu memenuhi kebutuhan masyarakat akan buku sekolah, buku panduan kreativitas dan buku tentang penanggulangan sampah atau banjir.

Literatur lain yang menjadi landasan bagi penelitian ini adalah situs resmi Kementrian Pekerjaan Umum dan Perumahan Rakyat Republik Indonesia. Pada situs tersebut tertulis bahwa Rumah Baca Apung yang terletak di Desa Tambak Lorok telah diresmikan pada tanggal 25 November 2016. Pada saat peresmian, Rumah Baca Apung telah dilengkapi dengan 300 eksemplar buku yang dapat dimanfaatkan oleh para pengunjung yang datang (Kementerian Pekerjaan Umum dan Perumahan Rakyat, 2016).

Berdasarkan tinjauan pustaka dari penelitian sebelumnya (Nurislaminingsih, 2016) dapat dipahami adanya kebutuhan masyarakat Tambak Lorok akan sebuah perpustakaan desa. Seiring dengan berjalannya waktu, kebutuhan masyarakat terhadap perpustakaan desa telah terpenuhi dengan berdirinya Rumah Baca Apung Tambak Lorok yang didirikan oleh Kementerian PUPR (2016). Berkaitan dengan hal tersebut, penelitian ini dilakukan guna mengkaji pemanfaatan Rumah Baca Apung oleh masyarakat.

Hasil dari penelitian ini diharapkan dapat memberikan gambaran tentang kegiatan yang dilakukan warga Tambak Lorok di Rumah Baca Apung yang merupakan representasi dari perpustakaan desa. Oleh sebab itu peneliti menggunakan literatur yang bersumber dari Undang-Undang No 43 Tahun 2007 tentang Perpustakaan pasal 3 dan pasal 4 yang menjelaskan tentang fungsi dan tujuan didirikannya sebuah perpustakaan. Pada pasal 3 tertulis bahwa "perpustakaan berfungsi sebagai wahana pendidikan, penelitian, pelestarian, informasi dan rekreasi untuk meningkatkan kecerdasan dan keberdayaan bangsa". Pasal 4 Undang-Undang No 43 Tahun 2007 tentang Perpustakaan juga menjelaskan hal senada yakni "perpustakaan bertujuan untuk memberikan layanan kepada pemustaka, meningkatkan kegemaran membaca, serta memperluas wawasan dan pengetahuan untuk mencerdaskan kehidupan bangsa”.

\section{METODE PENELITIAN}

Penelitian ini bertujuan untuk mengetahui kegiatan yang dilakukan warga pada Rumah Baca Apung dan alasan yang melatarbelakangi kegiatan tersebut. Penelitian ini menggunakan metode kualitatif dengan pendekatan studi kasus. Denzin dan Lincoln (2009) menjelaskan penelitian kualitatif merupakan penelitian yang mencakup pendekatan interpretatif dan naturalistik terhadap subjek kajiannya dan berguna untuk menggambarkan makna kesehariaan atau problematis kehidupan seseorang. Yin (2015) mengungkapkan studi kasus merupakan strategi yang lebih cocok bila penelitian bertujuan untuk menjelaskan pertanyaan how dan why serta fokus penelitiannya terletak pada fenomena kontemporer (masa kini) pada kehidupan nyata.

Data pada penelitian ini bersumber pada hasil wawancara, studi dokumen dan observasi (Yin, 2015). Informan dalam penelitian ini 
berjumlah 9 orang, dengan rincian 3 warga yang pernah memanfaatkan Rumah Baca Apung (informan 1, 2 dan 3). Informan lain yaitu 1 orang aparat desa selaku penanggungjawab (informan 4) dan 1 orang petugas sekaligus pemegang kunci Rumah Baca Apung (informan 5). Informan selanjutnya terdiri dari 3 orang warga sekitar yang menyatakan tidak pernah memanfaatkan Rumah Baca Apung (informan 6, 7 dan 8) serta 1 orang sukarelawan yang pernah mengajar di Rumah Baca Apung (informan 9).

\section{HASIL DAN PEMBAHASAN}

Bagian ini menjelaskan pemanfaatan Rumah Baca Apung oleh warga Tambak Lorok dan alasan yang menyertai kegiatan tersebut. Pemanfaatan dianalisis sesuai dengan UndangUndang No 43 Tahun 2007 tentang Perpustakaan pasal 3 yang menjelaskan fungsi dan pasal 4 yang menjabarkan tujuan berdirinya perpustakaan.

\section{a. Fungsi Perpustakaan}

Bagian ini menjelaskan pemanfaatan Rumah Baca Apung berdasarkan fungsi perpustakaan berdasarkan Undang-Undang No 43 Tahun 2007 tentang Perpustakaan pasal 3.

\section{1) Wahana pendidikan}

Kegiatan belajar bersama dengan salah seorang sukarelawan sempat dirasakan oleh informan 2 dan 3 beberapa waktu setelah peresmian Rumah Baca Apung. Dua siswa sekolah dasar tersebut mengaku belajar bahasa Inggris. Namun ketika ditanya nama atau asal-usul sukarelawan tersebut, keduanya tidak memberikan respon. Informan 2 kemudian menjelaskan bahwa kegiatan belajar bahasa Inggris bersama saat ini sudah tidak pernah dilaksanakan lagi oleh sukarelawan.

Identitas perwakilan sukarelawan yang pernah mengisi kegiatan belajar di Rumah Baca Apung dapat diketahui dari buku tamu, yakni HW (informan 9) dari komunitas ASA EDU. Pada saat peneliti mengkonfirmasi kegiatan ASA EDU dengan sodara HW, ketua ASA EDU tersebut menuturkan bahwa kunjungannya ke Rumah Baca Apung beberapa waktu silam bertujuan untuk mengetahui antusias anak-anak pesisir Tambak Lorok terhadap kegiatan yang bersifat edukatif. Informan 9 menjelaskan bahwa saat ini anggota ASA EDU sedang merancang pembentukan sebuah komunitas baru khusus untuk mengisi kegiatan belajar di Rumah Baca Apung.

Konfirmasi pemanfaatan Rumah Baca Apung sebagai tempat belajar bagi anak usia sekolah juga peneliti lakukan dengan informan 4. Bapak yang bertempat tinggal di depan Rumah Baca Apung tersebut menjelaskan bahwa selama ini pengunjung yang berniat untuk belajar hanya anak-anak Sekolah Dasar. Informan 4 mengakui belum ada remaja desa (anak usia Sekolah Menengah) yang tertarik untuk belajar di Rumah Baca Apung. Hal ini dibuktikan dalam buku daftar hadir pengunjung Rumah Baca Apung. Pada buku tersebut tercatat hanya guru dan siswa Sekolah Dasar Taqwiyatul Waton yang pernah berkunjung untuk melakukan pendidikan di luar sekolah.

Penjelasan informan 4 yang menyatakan belum ada remaja desa yang bersedia belajar di Rumah Baca Apung dibuktikan dengan pengakuan informan 6, seorang lulusan Sekolah Menengah Pertama yang kini sedang berusaha untuk menempuh pendidikan paket C. Informan 6 mengakui belum pernah mengunjungi Rumah Baca Apung dengan alasan tidak tertarik untuk berkunjung. Lebih lanjut informan mengatakan "ngapain ke Rumah Apung, di sana kan isinya buku cerita anak-anak. Pernah lewat di depan Rumah Apung, yang ada cuma ada anak kecil pada main".

Adanya kondisi remaja yang kurang berminat pada kegiatan membaca buku juga terjadi di Amerika. Hal ini dubuktikan melalui hasil penelitian dari Common Sense Media(Common Sense Media, 2014) yang mengutip hasil perhitungan NCES (National Center for Education Statistics) pada minat baca 2013. Hasil survei yang dilakukan di negara Amerika menunjukkan 
bahwa hobby membaca buku yang rutin dilakukan satu minggu sekali mulai menurun di kalangan anak usia 9 tahun. Kegemaran membaca tersebut semakin menurun seiring pertambahan usia anak menjadi remaja usia 17 tahun.

\section{2) Penelitian}

Informan 4 menjelaskan, konstruksi bangunan yang mengapung di atas tambak menjadi daya tarik tersendiri bagi dua warganegara Belanda untuk meneliti gedung Rumah Baca Apung. Para peneliti juga mengkaji pemanfaatan tenaga surya yang digunakan untuk penerangan di Rumah Baca Apung. Selain kedua peneliti tersebut, dalam buku tamu juga tercatat para peneliti dari beberapa universitas negeri dan swasta dari JawaTengah dan Yogyakarta.

Dengan demikian dapat dipahami fungsi penelitian di Rumah Baca Apung masih terbatas pada penelitian terhadap bangunan itu sendiri. Pihak pengelola belum mampu menyediakan buku atau literatur penunjang kegiatan penelitian bagi masyarakat yang datang, sehingga Rumah Baca Apung masih menjadi objek penelitian bukan penyedia informasi pendukung penelitian.

Penjelasan tentang keunikan Rumah Baca Apung terlihat dalam pernyataan Fadli (2016) yakni terletak pada struktur bangunan yang terapung di atas air dan memiliki tapak bangunan yang dibentuk dari B-foam yang dilapisi beton. Paduan teknologi foam dan beton juga dikenal dengan istilah "fonton". Teknologi muring atau semacam besi besar yang menghujam dari dek ke perairan juga diterapkan dalam pembangunan Rumah Baca Apung. Teknologi tersebut bekerja seperti fungsi jangkar pada perahu, sehingga Rumah Baca Apung tetap stabil meski di permukaan tambak yang memiliki riak gelombang. Teknologi hasil inovasi tim Balitbang Kementrian PUPR lainnya yang diterapkan pada bangunan Rumah Baca Apung berupa penggunaan panel surya yang dipasang di atap bangunan.

\section{3) Pelestarian}

Fungsi pelestarian koleksi di Rumah Baca Apung belum dapat dilaksanakan oleh pihak pengelola. Tindakan perusakan buku pernah disaksikan oleh informan 3 yang mengatakan "Pernah ada yang bawa buku, terus disobek, dibawa pulang, aku tahu sobekkannya." Hal ini dibenarkan oleh informan 5 selaku sukarelawan penjaga Rumah Baca Apung. Informan 5 juga menceritakan sebagian besar buku yang dipinjam oleh anak-anak (untuk di bawa pulang) tidak dikembalikan lagi pada petugas. Saat peneliti menanyakan upaya untuk menertibkan proses peminjaman koleksi, misalnya dengan sistem denda, juru kunci Rumah Baca Apung tersebut menjawab singkat dengan senyum datar "Ndak ada denda. Biarkan saja." Ekspresi informan 5 menyiratkan adanya harapan untuk merapihkan kegiatan peminjaman buku, namun demikian sistem denda dinilai bukan solusi yang tepat.

Kurangnya pengetahuan pengurus Rumah Baca Apung terhadap pengelolaan perpustakaan membuat fungsi pelestarian belum dapat dijalankan secara optimal. Hasil wawancara dengan informan 5 menunjukkan bahwa pengelola Rumah Baca Apung sampai saat ini belum pernah mendapatkan pelatihan tentang tata cara pengelolaan perpustakaan. Hal yang sama juga terjadi di perpustakaan desa Jiworejo. Kurangnya informasi terkait pengelolaan perpustakaan masih menjadi masalah utama dalam pengembangan perpustakaan di desa tersebut (Sofianto,-2015).

Kondisi buku cerita yang sudah rusak membuat informan 8 tidak berminat untuk mengunjungi Rumah Baca Apung. Siswa Sekolah Dasar tersebut beralasan tidak tertarik untuk membaca buku cerita yang sudah yang sobek dan kotor. Berikut kutipan ungkapan informan 8 "Ndak mau kesana. Bukunya kotor banyak debu. Terus banyak yang sobek-sobek. Jadi ndak bisa dibaca". 


\section{4) Informasi}

Fungsi informasi pada Rumah Baca Apung sudah terpenuhi meskipun informasi yang ada di Rumah Baca Apung lebih sering disampaikan dalam bentuk lisan. Pemberian informasi tersebut dilaksanakan bersamaan dengan kegiatan diskusi para warga di Rumah Baca Apung. Informan 5 yang selama ini bertanggungjawab memenuhi kebutuhan warga pada Rumah Baca Apung berasumsi masyarakat yang berada di sekitar belum sepenuhnya merasa memiliki Rumah Baca Apung. Tingkat kebutuhan informasi masyarakat juga masih rendah.

Berbanding terbalik dengan kenyataan tersebut, sesungguhnya wilayah pesisir menyimpan banyak pengetahuan yang dapat diinformasikan kepada masyarakat luas. Pengetahuan lokal yang menjadi ciri khas masyarakat pesisir dapat dibagikan kepada siapa saja yang membutuhkan. Satria -(2014) berpendapat pengetahuan yang menjadi ciri khas masyarakat pesisir antara lain cara menangkap ikan secara tradisional yang didapat dari kegiatan belajar kepada orang tua, cara membaca sistem kalender dan penunjuk arah berdasarkan rasi bintang, cara mengenali kondisi laut hanya dengan melihat warna air atau ketenangan gelombang serta cara mengawetkan perahu dengan cara pengasapan.

Pengetahuan lokal yang dimiliki oleh masyarakat pesisir juga berguna untuk menjaga keselamatan warga dari musibah. Tradisi lisan Smong dipercaya telah menyelamatkan sebagian besar warga dari bencana tsunami yang menimpa Aceh pada 26 Desember 2004 dan 28 Maret 2005. Smong (kondisi gelombang pasang surut air laut yang berbeda dari biasanya) telah dipercaya sebagai alarm bagi warga pesisir untuk segera mengungsi ke tempat yang lebih tinggi. Dengan demikian, masyarakat akan terbebas dari arus tsunami (Syafwina, 2014).

Manfaat perpustakaan umum sebagai pusat informasi telah lebih dahulu terangkum dalam penelitian yang dilakukan di Afrika milik Fuegi, SegbertElbert and Lipeikaite -(2011). Hasil dari penelitian tersebut menunjukkan bahwa perpustakaan umum tidak lagi dipandang sebagai lembaga yang melayani penyimpanan dan peminjaman buku atau sebagai tempat belajar semata. Perpustakaan diharapkan menjadi agen perubahan untuk meningkatkan perkembangan inovasi bagi masyarakat dengan cara menyediakan informasi sekaligus fasilitas penyuluhan tentang kesehatan, pertanian, budaya dan kewirausahaan.

\section{5) Rekreasi}

Berdasarkan hasil pengamatan awal peneliti, Rumah Baca Apung pernah dimanfaatkan oleh mahasiswa yang sedang menjalankan Kuliah Kerja Nyata untuk mengadakan kegiatan senam bersama masyarakat. Keceriaan dan kebahagiaan anak-anak terlihat jelas saat menggerakan badan mengikuti aba-aba instruktur senam.

Rumah Baca Apung juga pernah dimanfaatkan oleh masyarakat sebagai objek rekreasi. Informan 4 menceritakan pengalaman yang pernah berbincangbincang dengan pengunjung yang mengakui sengaja datang untuk melihat bangunan Rumah Baca Apung. Berikut pernyataan informan 4 tersebut "Pernah ada rombongan yang datang terus foto-foto di depan Rumah Baca Apung." Pengakuan Rumah Baca Apung sebagai destinasi wisata juga dapat diketahui dalam buku tamu. Pada buku tersebut terdapat pengunjung yang mengisi kolom tujuan kedatangan dengan tulisan "Wisata keluarga" dan kalimat "Kunjungan ke lokasi yang berpotensi wisata".

Sebuah surat kabar versi online juga mengaitkan antara keberadaan Rumah Baca Apung dengan objek wisata. Adanya Rumah Baca Apung pertama di Indonesia yang berlokasi di desa Tambak Lorok juga diharapkan menjadi objek rekreasi yang pertama di desa tersebut. Hal ini didasarkan 
pada hasil wawancara reporter dengan Menteri Pekerjaan Umum dan Perumahan Rakyat, bapak Basuki Hadimuldjono. Bapak Menteri berharap kelak wilayah Tambak Lorok dapat menjadi tempat wisata baru di Semarang(Nurdin, 2016).

Pembangunan lokasi perpustakaan yang memiliki tujuan agar dekat dengan kawasan wisata telah lebih dahulu dilakukan oleh Perpustakaan Umum Kabupaten Rembang - Jawa Tengah. Hasil penelitian Kamaliyah (2015) menujukkan bahwa terdapat pengaruh antara pemindahan Perpustakaan Umum Kabupaten Rembang ke Lokasi Pariwisata Pantai Kartini dengan minat kunjungan responden. Minat kunjungan tersebut didasarkan pada rasa ingin tahu, keadaan lingkungan dan kebutuhan informasi.

Pembentukan perpustakaan apung sebagai tempat rekreasi telah dilakukan oleh warga Amerika pada Lilac Museum Steamship di New York. Pembuatan perpustakaan apung tersebut ditujukan untuk membongkar kebiasaan lama bahwa menulis dan membaca hanya dapat dilakukan di ruangan. Perpustakaan di atas kapal tersebut memiliki ruang terbuka di bagian deck yang berfungsi sebagai tempat membaca dan bertukar pikiran bagi para pengunjung sembari menikmati pemandangan lautan -(Floating Library, 2014).

\section{b. Tujuan Perpustakaan}

Pada bagian ini akan dijelaskan pemanfaatan Rumah Baca Apung berdasarkan tujuan perpustakaan berdasarkan UndangUndang No 43 Tahun 2007 tentang Perpustakaan pasal 4.

\section{1) Layanan kepada Pemustaka}

Informan 4 menjelaskan layanan yang dapat diberikan oleh pengelola Rumah Baca Apung pada saat ini masih sebatas pada penyediaan ruangan untuk pertemuan warga. Bapak yang menjabat sebagai ketua RT tersebut membebaskan seluruh warga yang tinggal di wilayah Tambak Lorok untuk menggunakan ruangan Rumah Baca Apung sebagai balai pertemuan, baik untuk kepentingan rapat keluarga atau rapat desa. Rumah Baca Apung juga pernah dimanfaatkan untuk acara halalbihalal (acara saling bersalaman di Hari Raya Idul Fitri) antara aparat desa dan warga.

Menanggapi hal tersebut, pengurus Rumah Baca Apung dapat mengadaptasi keragaman layanan yang diberikan oleh salah satu perpustakaan umum di Cina. Perpustakaan tersebut telah memberikan berbagai layanan untuk berbagai kalangan masyarakat, seperti untuk dewasa, pemuda dan anak-anak, dan orang berkebutuhan khusus (difabel). Kegiatan yang diadakanpun beragam, seperti kaligrafi, lukisan, fotografi, pembacaan, kompetisi, nyanyian, dan tarian. Selain itu, bagi pengunjung usia dewasa diberikan layanan khusus berupa pelatihan keterampilan -(Ping, Shang, \& Zenmeng, 2013).

Layanan Rumah Baca Apung yang masih terbatas pada pemanfaatan ruangan juga dibenarkan oleh informan 5, salah satu warga Tambak Lorok yang memiliki kepedulian untuk menjaga kebersihan Rumah Baca Apung. Informan 5 menjelaskan sering diminta tolong membukakan gembok Rumah Baca Apung oleh beberapa aparat desa yang hendak mengadakan rapat di tempat tersebut.

Fungsi Rumah Baca Apung sebagai tempat untuk berdiskusi warga seperti yang dijelaskan oleh Sutarno (2008) bahwa "perpustakaan desa dapat dijadikan wahana dialog dan diskusi untuk memecahkan masalah-masalah yang dihadapi masyarakat serta mempererat kesatuan dan persatuan".

\section{2) Peningkatan Gemar Membaca}

Di awal berdirinya, Rumah Baca Apung pernah dimanfaatkan oleh anak usia sekolah dasar untuk kegiatan membaca buku. Namun seiring berjalannya waktu, kegiatan membaca menjadi semakin jarang dilakukan. Diakui oleh informan 4, Rumah Baca Apung membutuhkan sukarelawan yang bersedia mendampingi anak-anak 
untuk kegiatan membaca dan belajar.

Hal tersebut diperkuat dengan pengakuan informan 3 yang mengatakan lebih sering memanfaatkan Rumah Baca Apung sekedar untuk bermain bersama teman. Siswa SD tersebut beralasan karena kurangnya pilihan ragam cerita yang terdapat dalam buku yang menjadi koleksi, sehingga menimbulkan rasa malas untuk membaca.

Aktivitas anak-anak yang menghabiskan waktu luang untuk bermain di Rumah Baca Apung juga terlihat mendapat dukungan dari orang tua. Peneliti melihat seorang ibu mengantarkan anak untuk bermain bersama teman di lokasi tersebut. Ibu tersebut (informan 7) hanya mengantarkan si anak sampai di pintu masuk, kemudian beranjak pulang. Ketika peneliti menanyakan alasan sang ibu tidak masuk ke dalam Rumah Baca Apung, ibu rumah tangga tersebut memberikan jawaban bahwa tidak terdapat apa apa di dalam bangunan itu.

Berdasarkan informan 7 tersebut, dapat dipahami bahwa informan membutuhkan sarana untuk bermain bersama anak di Rumah Baca Apung. Informan juga terkesan membiarkan si anak untuk membaca sendiri, tanpa ada kesadaran untuk mendampingi anak membaca. Peningkatan gemar membaca bagi masyarakat yang berada di sekitar Rumah Baca Apung menjadi hal yang harus terus dilakukan oleh penanggung-jawab pengelola perpustakaan desa. Hal ini dapat dilakukan melalui upaya menyediakan fasilitas membaca dan belajar yang sesuai dengan kebutuhan, ciri khas, karakteristik dan keunikan masyarakat setempat(Sutarno, 2008).

Sesuai dengan nama Rumah Baca Apung yang terlukis di dinding atas bangunan, sudah selayaknya tempat tersebut menjadi wadah untuk kegiatan membaca. Pada penelitian Nurislaminingsih dan Partini (2016) kegiatan membaca yang ada di perpustakaan dapat dilakukan dengan cara story telling dan story reading. Dua kegiatan membaca tersebut berguna untuk mengurangi aktivitas anak-anak yang kurang bermanfaat, seperti berkelahi, mengunjungi mall dan bermain game dan gadget. Selain itu, kegiatan story telling juga dapat berfungsi sebagai media pelestari budaya bangsa, salah satunya dengan kegiatan lomba bercerita menggunakan bahasa daerah (Jawa).

Adanya usaha untuk meningkatkan kualitas perpustakaan umum telah dilakukan di Cumbria dengan cara menerapkan prinsip Orientasi Strategi. Pihak perpustakaan umum tersebut senantiasa berusaha untuk memenuhi kebutuhan yang beragam dari masyarakat sekitar pada perpustakaan. Bauran strategi juga dilaksanakan untuk menjalankan prinsip tersebut, seperti pembuatan jaringan komunikasi, memotivasi pustakawan, hingga terus menciptakan inovasi layanan perpustakaan (Sen, 2014).

\section{3) Menambah Wawasan dan Pengetahuan}

Berdasarkan hasil wawancara dengan informan 4, lokasi tersebut pernah dimanfaatkan untuk kegiatan penyuluhan dari berbagai pihak yang peduli terhadap masyarakat Tambak Lorok. Pernyataan tersebut diperkuat dengan catatan di buku tamu Rumah Baca Apung yang berisi daftar pengunjung dan tujuan kegiatan. Petugas Palang Merah Indonesia dari Kota Semarang pernah mengadakan kegiatan sosial donor darah. Perwakilan dari puskesmas setempat juga pernah mengadakan kegiatan Kelas Ibu Hamil dan kelas Balita. Acara bertemakan kesehatan juga pernah digelar oleh mahasiswa, yakni sosialisasi penyakit demam berdarah dan bahaya sampah plastik.

Berdasarkan buku tamu juga dapat diketahui penyuluhan dalam bidang sosial lainnya yang pernah dilaksanakan bagi warga yang bertempat tinggal di sekitar Rumah Baca Apung. Sosialiasasi tersebut antara lain pelatihan kewirausahaan, pengolahan mangrove, penyuluhan keselamatan nelayan, pelatihan memasak dan pelatihan hidroponik. Seluruh kegiatan 
tersebut berguna sebagai tambahan pengetahuan dan pengalaman kunjungan ke perpustakaan desa bagi masyarakat.

Adanya pelatihan tersebut membantu memudahkan para warga agar terampil untuk menerapkan ilmu yang didapat kedalam kehidupan sehari-hari. Hal ini seperti yang disampaikan oleh Sutarno (2008) bahwa keterampilan merupakan pengetahuan praktis dan pragmatis yang diterapkan dalam kegiatan di rumah atau tempat kerja. Kegiatan ini dilakukan dengan cara belajar mengenai budidaya, usaha ekonomi kecil, memasak dan tata boga, serta meningkatkan kualitas kerajinan tangan dan industri rumah tangga.

Penjelasan tentang fungsi perpustakaan sebagai tempat untuk menambah pengetahuan dan wawasan sejalan dengan penelitian Pacheco dan Escamilla (2016). Pada penelitian tersebut dijelaskan bahwa sumber daya manusia yang ada di perpustakaan umum harus mampu melakukan banyak hal, seperti pengembangan inovasi perlengkapan yang dapat membantu proses belajar bagi warga di sekitar perpustakaan umum. Kemampuan untuk mengadakan dan mengelola koleksi juga sangat diperlukan bagi pengurus perpustakaan umum. Hal ini berguna untuk membantu pemustaka dalam menemukan informasi yang dibutuhkan.

\section{E. KESIMPULAN}

Rumah Baca Apung yang terdapat di Desa Tambak Lorok sejatinya merupakan representasi dari perpustakaan desa, namun demikian fungsi dan tujuan pendirian perpustakaan belum sepenuhnya dapat diterapkan di lokasi tersebut. Pemanfaatan Rumah Baca Apung belum berdasarkan fungsi pendidikan, fungsi penelitian dan fungsi pelestarian. Hal tersebut dikarenakan Rumah Baca Apung belum memiliki mainan edukatif serta koleksi yang cukup memadai dalam jumlah dan kualitas. Koleksi yang ada juga belum menunjang kebutuhan para peneliti yang datang. Namun demikian, pemanfaatan fungsi rekreasi telah terlaksana pada Rumah Baca Apung pertama di Indonesia tersebut.

Penggunaan Rumah Baca Apung Tambak Lorok sebagai tempat untuk meningkatan kebiasaan gemar membaca yang menjadi tujuan pembuatan Rumah Baca Apung juga belum terlihat nyata. Kurangnya sukarelawan yang bersedia menjadi pendamping kegiatan belajar bagi anak-anak pesisir menjadi kendala bagi usaha menghidupkan budaya baca dan belajar di lokasi tersebut. Rumah Baca Apung kini lebih sering dimanfaatkan sebagai tempat untuk berdiskusi bagi warga, tempat untuk rapat bagi aparat desa serta media untuk kegiatan sosialisasi atau penyuluhan dari berbagai instansi.

\section{DAFTAR PUSTAKA}

Common Sense Media. Children, teens and reading: Common sense media research brief. (2014). Diakses 20 Juli 2017 dari https://www.commonsensemedia.org/resea $\mathrm{rch} /$ children-teens-and-reading.

Denzin, N. K., \& Lincoln, Y. S. (2009). Handbook of qualitative research. Yogyakarta: Pustaka Pelajar.

Fadli, R. (2016). Segera hadir, perpustakaan dan jembatan apung pertama di Indonesia. Dinamika Riset, III, 36-38. diakses 22 Juli 2017 dari http://litbang.pu.go.id/ litbang/uploads/products/dinamikareset/majalah-dinamika-riset-edisi-3-tahun2016.pdf. .

Floating Library. (2014). A pop - up floating library: A board the Lilac Museum Steamship (press release). Diakses 20 Juli 2017 dari http://www.floatinglibrary.org/ resources/PRESS-RELEASE.pdf.

Fuegi, D., Segbert-Elbert, M., \& Lipeikaite, U. (2011). Public libraries in Africa - agents for development and innovation? Current Perceptions of local stakeholders. Presented at the World Library and Information Congress : 77th IFLA General Conference and Assembly, Puerto Rico: IFLA. Diakses 14 Agustus 2017 dari https://www.ifla.org/ past-wlic/2011/183-fuegi-en.pdf. . 
Kamaliyah, A. (2015). Pengaruh pemindahan Perpustakaan Umum Kabupaten Rembang ke lokasi pariwisata Pantai Kartini terhadap minat kunjung pemustaka. Berkala Ilmu Perpustakaan van Informasi, XI (2) 8-15.

Kementerian Pekerjaan Umum dan Perumahan Rakyat. (2016). Menteri Basuki resmikan balai warga dan rumah baca apung pertama di Indonesia. Diakses 2 September $2017 \mathrm{~d}$ a r i http://pu.go.id/berita/11934/MenteriBasuki-Resmikan-Balai- W a r g a - d a n Rumah-BacaApung-Pertama-di-Indonesia.

Nurdin, N. (2016, November 25). Rumah Apung di Semarang bakal Jadi kawasan wisata Kompas.com. Kompas. Diakses 18 Juli $2017 \quad$ d a r i http://regional.kompas.com/read/2016/11/2 5/16153451/rumah.apung.di.semarang.bak al.jadi.kawasan.wisata.

Nurislaminingsih, R. (2016). Attitudes of fishermen in Tambak Lorok on library. Presented at the The $1^{\text {st }}$ International Conference on Southeast Asia Maritime World, Semarang, 16-17 November 2016.

Nurislaminingsih, R., \& Partini. (2016). Persepsi pemustaka dari latar belakang sosial yang berbeda terhadap fungsi perpustakaan (Studi di Perpustakaan Kota Yogyakarta). Berkala Ilmu Perpustakaan dan Informasi, 12(2), 159-165.

Pacheco, F. H., \& Escamilla, D. Q. (2016). Human resources in Mexican public libraries: And exploratory inquiry. Investigacion Bibliotecologica, 30(68).
Ping, W., Shang, H., \& Zenmeng, W. (2013). Chinese public library services for vulnerable groups. Chinese Librarianship: An International Electronic Journal, (35). Diakses 11 Agustus 2017 dari http://www.iclc.us/cliej/cl35WHW.pdf.

Satria, A. (2014). Pengantar sosiologi masyarakat pesisir. Jakarta: Yayasan Pustaka Obor Indonesia.

Sen, B. (2014). Multiple strategic orientations: the public library as a societal organization. Procedia-Social and Behavioral Sciences, 147, 111-119.

Sofianto, A. (2015). Model pendayagunaan perpustakaan desa untuk peningkatan pendidikan masyarakat di Desa Jiworejo, Kecamatan Jiken, Kabupaten Blora. Jurnal Litbang Provinsi Jawa Tengah, 13(1), 11-24.

Sutarno, N. (2008). Membina perpustakaan desa. Jakarta: Sagung Seto. Jakarta: Sagung Seto.

Syafwina. (2014). Recognizing indigenous knowledge for disaster management: Smong, early warning system from Simeulue Island, Aceh. Procedia Environmental Sciences, 20,573-582.

Undang-Undang No 43 Tahun 2007 tentang Perpustakaan (2007). Diakses 1 Juni 2017

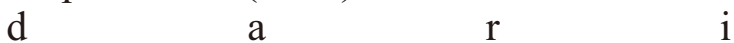
http://www.pnri.go.id/law/undang-undangnomor-43-tahun-2007-tentangperpustakaan/..

Yin, R. K. (2015). Studi kasus: Desain dan metode. Jakarta: Rajawali Pers. 